\title{
KAJIAN PENGURANGAN $\mathrm{SO}_{2}$ DAN NO $\mathrm{X}_{\mathrm{X}}$ DARI GAS BUANG HASIL PEMBAKARAN DENGAN AKSELERATOR
}

\author{
Sukarsono \\ Puslitbang Teknologi Maju BATAN, Yogyakarta
}

\begin{abstract}
ABSTRAK
KAJLAN PENGURANGAN SO ${ }_{2}$ DAN NO ${ }_{X}$ DARI GAS BUANG HASIL PEMBAKARAN DENGAN AKSELERATOR. Emisi gas nitrogen oksida dan sulfur oksida merupakan salah satu sumber pencemaran dan kerusakan lingkungan. Gas-gas tersebut disebut gas asam, dapat menyebabkan hujan asam, efek rumah kaca secara tidak langsung, merusakkan hutan, menghancurkan hasil panen. merusakkan lahan pertanian dan kehidupan hewan, korosi bangunan dan menimbulkan masalah-masalah kesehatan. Pengurangan gas berbahaya dalam gas hasil pembakaran banyak dilakukan dengan penyerapan gas $\mathrm{SO}_{2}$, dikombinasi dengan proses pencegahan terjadinya gas $\mathrm{NO}_{X}$ melalui pembakaran ulang gas $N O_{X}$ atau reduksi gas hasil pembakaran baik secara katalitik maupun tidak Cara tersebut menimbulkan banyak limbah cair. Cara baru yang tidak menimbulkan limbah cair dan dapat menghilangkan $\mathrm{NO}_{X}$ dan $\mathrm{SO}_{2}$ secara simultan dapat dilakukan dengan iradiasi menggunakan berkas elektron. Gas Hasil Pembakaran diiradiasi menghasilkan senyawa radikal yang memicu reaksi $\mathrm{NO}_{X}$ menjadi asam nitrat dan $\mathrm{SO}_{2}$ menjadi asam sulfat yang apabila direaksikan dengan ammoniak menghasilkan ammonium sulfat dan ammonium nitrat. Kedua hasil samping dapat digunakan sebagai pupuk tanaman. Dengan proses baru ini biaya investasi lebih besar tetapi biaya opeasional menjadi murah dan dihasilkan produks samping sehingga biaya keseluruhan menjadi murah.
\end{abstract}

\section{ABSTRACT}

REMOVING SO $\mathrm{SAND}_{2} \mathrm{NO}_{X}$ FROM THE FLUEGAS BY ACCELERATOR. The emission of sulfur oxide and nitrogen oxide from fossil fuel burning is one of the sources of environmental pollution and environmental degradation. These gases are named as acid gases, causing acid rain, the indirect green house effect, damages forest, agriculture fields and flora, building corrosion and also caused many public health problems. Treatment of the dangerous gases is doing by scrubbing of $\mathrm{SO}_{2}$ using calcium base combined by reburn $N O_{X}$ process or catalytic/non catalytic reduction process for reducing $N O_{X}$ in the flue gas. The new process was introduced. Using the electron beam machine, flue gas was irradiated, producing radical substances that make a reaction with $\mathrm{NO}_{X}$ and $\mathrm{SO}_{2}$ to be nitric acid and sulfuric acid. By introducing ammonia in the gas phase, the acid will react with ammonia to be ammonium sulfate and ammonium nitrate. These by products is used as plant fertilizer. This new process needs higher investation cost and lower operational cost. The total cost of $\mathrm{NO}_{X}$ and $\mathrm{SO}_{2}$ treatment of the new process is lower then the old process.

\section{PENDAHULUAN}

Emisi gas berbahaya dari alat proses atau pembakaran bahan bakar seperti $\mathrm{SO}_{\mathrm{x}}\left(\mathrm{SO}_{2}\right.$ dan $\left.\mathrm{SO}_{3}\right)$ dan $\mathrm{NO}_{\mathrm{X}}\left(\mathrm{NO}, \mathrm{NO}_{2}\right)$ merupakan sumber polusi lingkungan terbesar, yang berakibat pencemaran dan perusakan lingkungan. Gas-gas tersebut disebut gas asam, dapat menyebabkan hujan asam yaitu air hujan yang mengandung asam karena reaksi antara gas dengan air. Gas asam juga menyebabkan efek rumah kaca secara tidak langsung. Hujan asam merusakkan hutan, menghancurkan hasil panen, merusakkan lahan pertanian dan kehidupan hewan, korosi bangunan dan menimbulkan masalah-masalah kesehatan ${ }^{(1,2)}$.

Emisi gas $\mathrm{SO}_{2}$ dan $\mathrm{NO}_{\mathrm{X}}$

Peraturan tentang langit bersih yang digalakkan dibanyak negara termasuk Indonesia menyebabkan keharusan bagi perusahaan untuk mengontrol polutan udara 
dari plant mereka. Kebutuhan energi untuk tambahan proses ini sangat besar, karena kandungan polutan gas buang, besar dan bervariasi tergantung dari asal gas buang tersebut. Akibat peraturan-peraturan tersebut penyediaan energi untuk menghilangkan emisi polutan menjadi besar juga. Untuk pembatasan terhadap emisi gas berbahaya yang mengancam kelestarian lingkungan, perlu ditetapkan oleh negara batas emisi yang diijinkan keluar dari plant tertentu ${ }^{(1)}$.

Batas emisi gas berbahaya yang diijinkan untuk bebarapa negara sangat bervariasi tergantung dari jenis plant, ukuran plant dan bahan bakar yang digunakan. Data tersebut dapat dilihat dalam tabel $1^{(1)}$.

Tabel 1. Batas Emisi $\mathrm{SO}_{2}$ dan $\mathrm{NO}_{\mathrm{x}}$ dari beberapa negara

\begin{tabular}{|l|c|c|c|c|}
\hline \multirow{2}{*}{ Negara } & \multicolumn{2}{|c|}{ Plant baru $\left(\mathrm{mg} / \mathrm{Nm}^{3}\right)$} & \multicolumn{2}{c|}{ Plant lama $\left(\mathrm{mg} / \mathrm{Nm}^{3}\right)$} \\
\cline { 2 - 5 } & $\mathrm{SO}_{2}$ & $\mathrm{NO}_{x}$ & $\mathrm{SO}_{2}$ & $\mathrm{NO}_{x}$ \\
\hline Australia & $200-1.620$ & $200-400$ & $200-2.000$ & $200-400$ \\
\hline Canada & 715 & 740 & - & - \\
\hline Denmark & $400-2.000$ & $650(200)$ & 810 & - \\
\hline Finlandia & $380-2.540$ & $200-400$ & $620-1.540$ & $200-620$ \\
\hline Perancis & $400-2.000$ & $650-1.300$ & $400-2.000$ & - \\
\hline German & $400-2.000$ & $200-500$ & $400-2.500$ & $200-1.300$ \\
\hline Grase & $200-2.000$ & $650-1.300$ & $400-2.000$ & - \\
\hline Irlandia & $400-2.000$ & $650-1.300$ & - & - \\
\hline Itali & $400-2.000$ & $200-650$ & $400-2.000$ & - \\
\hline Jepang & - & $410-510$ & - & $620-720$ \\
\hline Polandia & $540-1.755$ & 460 & $675-4.160$ & - \\
\hline Portugal & $400-2.000$ & $650-1.300$ & - & - \\
\hline Spanyol & $400-2.000$ & $650-1.300$ & $2.400-9.000$ & - \\
\hline Swedia & $160-540$ & 140 & $160-920$ & $(140-560)$ \\
\hline Swis & $430-2.145$ & $200-500$ & $430-2.145$ & $200-500$ \\
\hline Inggris & $400-3.000$ & $650-300$ & $2.000-3.000$ & - \\
\hline USA & $750-1.480$ & $615-980(550)$ & 1480 & - \\
\hline
\end{tabular}

Sumber energi dan dampaknya terhadap lingkungan

Di dalam bidang sumber energi, Indonesia mempunyai bermacam-macam sumber energi yang masih cukup banyak, tetapi beberapa sudah menipis cadangannya. Sumber sumber energi tersebut adalah minyak, batubara, gas alam, panas bumi, air, gelombang laut, beda panas laut, matahari dll. Minyak bumi yang pernah menjadi andalan di Indonesia pada masa lalu, cadangannya tercatat sebesar sekikar 10 milyar barrel (M bbl) dengan rincian 4,7 cadangan terbukti dan 5,02 M bbl merupakan cadangan potensial (3). Cadangan tersebut dapat menyediakan minyak bumi sampai 20 tahun dengan tingkat produksi 1,3 juta bbl per hari seperti saat ini. Tetapi apabila cadangan potensial tidak terbukti, maka dalam 7 tahun, cadangan minyak Indonesia akan habis ditambang ${ }^{(4)}$.

Produksi minyak mentah Indonesia 1,3 juta bbl/hari, dihasilkan oleh para KPS (Kontraktor Production Sharing) baik asing maupun domestik. Tetapi produksi oleh KPS domestik (Pertamina \& Medco), hanya 0,14 juta bbl/hari dan sisanya oleh KPS asing. Setelah disisihkan sebagian untuk membayar ongkos produksi pada KPS, sisanya dibagihasilkan (15\% KPS, $85 \%$ pemerintah RI). Dari bagi hasil tersebut 
perolehan pemerintah adalah : 700.000 bbl/hari. Kapasitas total kilang domestic saat ini sebesar 1,05 juta bbl/hari. Untuk keperluan kilang di Cilacap sejumlah $350.000 \mathrm{bbl} /$ hari minyak mentah diimpor dari Arab. Sehingga untuk memenuhi kebutuhan minyak bumi bagi kilang-kilang Indonesia, pemerintah masih mengimpor minyak dari luar negeri ${ }^{(5)}$.

Bahan bakar lain yang masih potensial untuk digunakan, adalah gas alam. Cadangan gas alam Indonesia 39 milyar ton dan baru termanfaatkan $5 \%$. Sumber energi panas bumi tersedia $20.000 \mathrm{MW}$ dan baru termanfaatkan $1 \%$. Cadangan gas bumi masih 178,1 trilyun CuFt. Sumber energi lain selain yang sudah disebut di atas, dapat dikatakan kecil untuk memenuhi kebutuhan energi yang semakin meningkat.

Pertumbuhan energi di Indonesia sebelum krissis moneter mencapai $15 \%$ ter tahun, dan terhenti pada waktu terjadi krisis moneter tahun 1997. Setelah melalui usaha yang keras, pada saat ini pertumbuhan energi diperkirakan $5 \%$, yang diharapkan masih meningkat seiring dengan membaiknya keadaan ekonomi Indonesia.

Salah satu sumber energi yang potensial untuk dikembangkan di Indonesia adalah batubara. Hanya sayang sebagian besar batubara Indonesia berupa lignit yaitu batubara muda. Batubara muda karena kandungan kandungan pengotor masih cukup besar kalau dibakar menghasilkan gas-gas yang bermacam-macam dan abu layang berupa debu yang lebih banyak. Untuk menjaga kelestarian alam, diperlukan biaya yang lebih banyak untuk mengolah gas buangan ini agar tidak berbahaya bagi lingkungan. Perkiraan konsumsi sumber energi dimasa yang akan datang dapat dilihat di Gambar $1^{(5)}$.

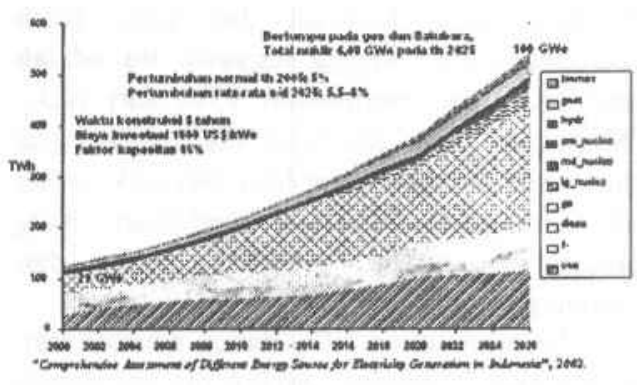

Gambar 1. Proyeksi Sumber Energi di Indonesia di Masa Yang Akan Datang

\section{Gas-gas dalam gas buang.}

Reaksi pembakaran adalah reaksi antara bahan bakar dengan oksigen dalam ruang pembakaran. Bahan bakar yang merupakan senyawa organik hidrokarbon bila dibakar menghasilkan gas $\mathrm{CO}_{2}$ dan $\mathrm{H}_{2} \mathrm{O}$ menurut reaksi :

$\mathrm{C}_{\mathrm{x}} \mathrm{H}_{\mathrm{y}}+(\mathrm{x}+1 / 2 \mathrm{y}) \mathrm{O}_{2} \rightarrow \mathrm{x} \mathrm{CO}_{2}+\mathrm{y} \mathrm{H}_{2} \mathrm{O}$

Senyawa hidrokarbon yang bermacammacam dan senyawa-senyawa lain yang ada dalam bahan bakar, menyebabkan hasil pembakaran tidak hanya karbon dioksida $\left(\mathrm{CO}_{2}\right)$ dan air $\left(\mathrm{H}_{2} \mathrm{O}\right)$ tetapi juga senyawa berbahaya seperti $\mathrm{SO}_{2}$ dan $\mathrm{NO}_{\mathrm{x}}$. Kadar gas $\mathrm{NO}_{\mathrm{X}}$ dan $\mathrm{SO}_{2}$ dalam gas hasil pembakaran dapat dilihat dalam Tabel 2 .

Tabel 2. Emisi $\mathrm{SO}_{2}$ dan $\mathrm{NO}_{\mathbf{X}}$ dari bahan bakar

\begin{tabular}{|c|l|c|c|}
\hline No & $\begin{array}{l}\text { Asal gas Hasil } \\
\text { Buang }\end{array}$ & $\begin{array}{c}\text { Emisi } \mathrm{SO}_{2} \\
\left(\mathrm{mg} / \mathrm{m}^{3}\right)\end{array}$ & $\begin{array}{c}\text { Emisi NOx } \\
\left(\mathrm{mg} / \mathrm{m}^{3}\right)\end{array}$ \\
\hline 1 & $\begin{array}{l}\text { Pembakaran } \\
\text { Batubara }\end{array}$ & $550-14.000$ & $300-1.800$ \\
\hline 2 & $\begin{array}{l}\text { Pembakaran } \\
\text { minyak ringan }\end{array}$ & $125-1.300$ & \\
\hline 3 & $\begin{array}{l}\text { Pembakaran } \\
\text { minyak berat }\end{array}$ & $0-25$ & \\
\hline
\end{tabular}

Pembentukan gas $\mathrm{NO}_{\mathrm{x}}$ dalam pembakaran bahan bakar

Emisi $\mathrm{NO}_{\mathrm{X}}$ dari pembakaran dapat dijelaskan sebagai sebagai emisi nitrogen oksida (NO) dan nitrogen dioksida $\left(\mathrm{NO}_{2}\right)$. 
Oksida yang dominan dan yang lebih berbahaya dari kedua senyawa itu adalah gas NO yang merupakan $95 \%$ dari $\mathrm{NO}_{\mathrm{X}}$. Meskipun juga terdeteksi $\mathrm{N}_{2} \mathrm{O}$ dalam gas hasil pembakaran yang bisa merusak ozone di Stratosfir, tujuan pengelolaan $\mathrm{NO}_{\mathrm{X}}$ adalah merubah menjadi $\mathrm{NO}_{2}$ dan pengambilan gas tersebut ${ }^{(6)}$.

Pembentukan $\mathrm{NO}_{\mathrm{x}}$ dalam pembakaran merupakan interaksi antara proses kimia, fisika dan panas berlangsung melalui 3 tahapan.

\section{Pembentukan $\mathrm{NO}_{\mathrm{x}}$ karena panas}

Oksidasi nitrogen dalam atmosfir pada suhu tinggi membentuk radikal oksigen. Atom berreaksi dengan nitrogen menghasilkan NO

$$
\begin{aligned}
& \mathrm{O}_{2} \Leftrightarrow 2 \mathrm{O} \\
& \mathrm{O}+\mathrm{N}_{2} \Leftrightarrow \mathrm{NO}+\mathrm{N} \\
& \mathrm{N}+\mathrm{O}_{2} \Leftrightarrow \mathrm{NO}+\mathrm{O} \\
& \mathrm{N}+\mathrm{OH} \Leftrightarrow \mathrm{NO}+\mathrm{H}
\end{aligned}
$$

\section{Pembentukan $\mathrm{NO}_{\mathrm{x}}$ dari Bahan bakar}

Pembentukan $\mathrm{NO}_{\mathrm{X}}$ dari bahan bakar disebabkan adanya senyawa hiterosiklik nitrogen yang ada dalam bahan bakar seperti piridin, piperidin dan guinolin yang terdapat dalam minyak dan rantai siklik maupun rantai terbuka nitrogen dalam batu bara. Senyawa-senyawa nitrogen ini yang menghasilkan gas NO. Jumlah maupun kecepatan pembentukan $\mathrm{NO}_{\mathrm{x}}$ dari senyawa nitrogen tergantung dari ikatannya masingmasing.

\section{Pembentukan $\mathrm{NO}_{\mathrm{x}}$ cepat}

Pembentukan $\mathrm{NO}_{\mathrm{X}}$ ini terjadi karena reaksi nitrogen dan radikal hidrokarbon selama pembakaran. Pembentukan $\mathrm{NO}_{\mathrm{X}}$ ini cepat terjadi pada pelepasan energi panas karena pembakaran. Sebagai permulaan terjadinya reaksi adalah pembentukan $\mathrm{HCN}$ sbb:

$$
\begin{aligned}
& \mathrm{CH}+\mathrm{N}_{2} \Leftrightarrow \mathrm{HCN}+\mathrm{N} \\
& \mathrm{CH}_{2}+\mathrm{N}_{2} \Leftrightarrow \mathrm{HCN}+\mathrm{NH}
\end{aligned}
$$

Selanjutnya $\mathrm{HCN}$ ini mereduksi senyawa nitrogen menjadi NO

\section{Penghilangan gas-gas berbahaya dalam gas buang}

Teknologi pengontrolan gas berbahaya dari suatu plant misalnya pembakaran batubara, bisa melalui dua jalan yaitu dengan modifikasi teknik pembakaran untuk mencegah terbentuknya atau penghilangan gas berbahaya yang ada dalam gas hasil pembakaran. Pencegahan terjadinya gas berbahaya, misalnya $\mathrm{NO}_{\mathrm{X}}$ dilakukan dengan pembakaran kembali $\mathrm{NO}_{\mathrm{x}}$ pada kondisi kekurangan udara dan dilanjutkan pembakaran pada suhu rendah untuk menyempurnakan reaksi. Sedangkan penanganan gas hasil pembakaran untuk mengurangi $\mathrm{NO}_{\mathrm{X}}$ yaitu dengan teknik reduksi katalitis selektif (SCR) dan reduksi non katalitis selektif (SNCR). Penyerapan gas berbahaya juga dilakukan dengan menyerap gas tersebut dengan bahan penyerap melalui kontak antara gas yang mengandung gas berbahaya dengan cairan penyerap dalam kolom absorbsi $(1,2,6,7,8,9,10)$

Skema proses pembersihan gas hasil pembakaran dapat dilihat dalam Gambar $2^{(7)}$

Abu layang yang terikut dalam gas hasil pembakaran dipisahkan dengan pemisah elektrostatis. Penyerapan gas berbahaya dalam gas hasil pembakaran dilakukan dengan cara mengkontakkan gas dengan penyerap kalsium hidroksida, yang mengikat gas menjadi senyawa kalsium sulfat dan kalsium nitrat. Dalam reaktor ini, reaksi disempurnakan dan kemudian dipompakan ke dalam tangki pengenap sehingga kalsium sulfat mengenap. Setelah dipisahkan kalsium sulfat dicampur dengan abu layang dari pemisahan menggunakan pemisah elektrotatis. 


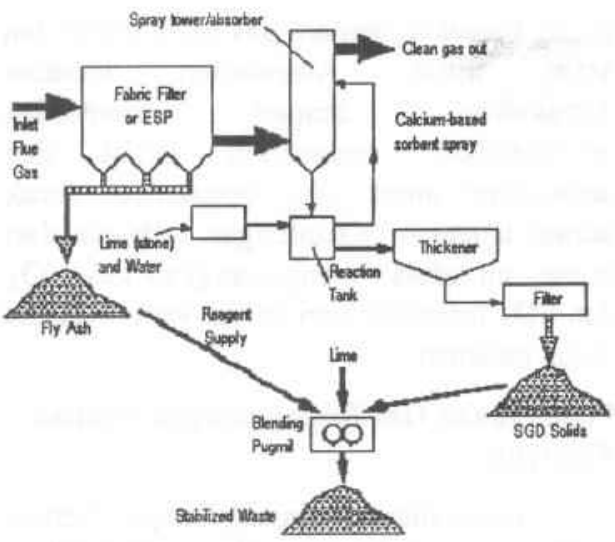

Gambar 2. Bagan penyerapan gas berbahaya dengan penyerap cair

Pembakaran ulang $\mathrm{NO}_{\mathrm{x}}$ adalah modifikasi proses pembakaran, sehingga pembentukan $\mathrm{NO}_{\mathbf{X}}$ diminimumkan . Pembakaran ulang $\mathrm{NO}_{\mathrm{X}}$ untuk mengurangi $\mathrm{NO}_{\mathrm{X}}$ dalam hasil pembakaran dilakukan melalui 3 tahapan. Tahap pertama gas pembentukan gas NO dengan interaksi bahan bakar dengan udara, tahap kedua adalah penambahan bahan bakar di bawah kondisi reduksi (kekurangan oksigen) untuk memproduksi radikal hidrokarbon yang bereaksi dengan $\mathrm{NO}_{\mathrm{X}}$ yang terbentuk, menghasilkan $\mathrm{N}_{2}$ dan tahapan ketiga adalah penambahan udara pada suhu rendah untuk menyempurnakan pembakaran ${ }^{(6)}$.

Karena biaya proses penyerapan ini tinggi, dan hasil samping yang diperoleh yaitu gibsun tidak banyak digunakan, maka kebanyakan negara berkembang tidak menggunakan penyerap ini, kecuali pada untuk gas-gas mempunyai kandungan $\mathrm{SO}_{\mathrm{X}}$ yang sangat tinggi.

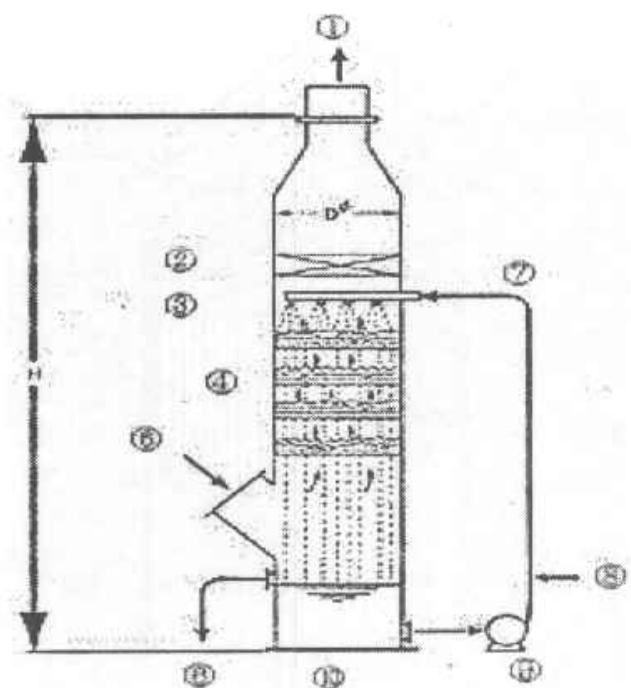

Keterangan

1. Keluaran Gas

6. Over Flow

2. Pemisah butiran

7. Re-sirkulasi

3. Nozzle Penyemprot

8. Aliran Cairan

4. Plate Berlubang

9. Pompa Sirkulasi

5. Masukan Gas

Gambar 3. Alat penyerap gas berbahaya dalam gas hasil pembakaran

Untuk menjaga lingkungan dan mendukung program langit bersih, perlu didapatkan cara penyerapan gas-gas berbahaya tersebut dengan biaya yang murah. Mesin berkas elektron yang merupakan akselerator elektron dengan energi rendah, mempunyai prospek untuk memecahkan permasalahan tersebut. Mesin berkas elektron merubah gas-gas tersebut menjadi asam sulfat dan asam nitrat, kemudian diikuti dengan langkah kedua mereaksikan asam dengan ammoniak. Hasil yang diperoleh adalah ammonium sulfat dan ammonium nitrat. Garam ammonium yang dihasilkan dapat berfungsi sebagai pupuk tanaman. Dengan demikian, proses ini mengubah bahan berbahaya menjadi bahan yang dibutuhkan petani untuk menyuburkan tanaman $^{(2)}$. 


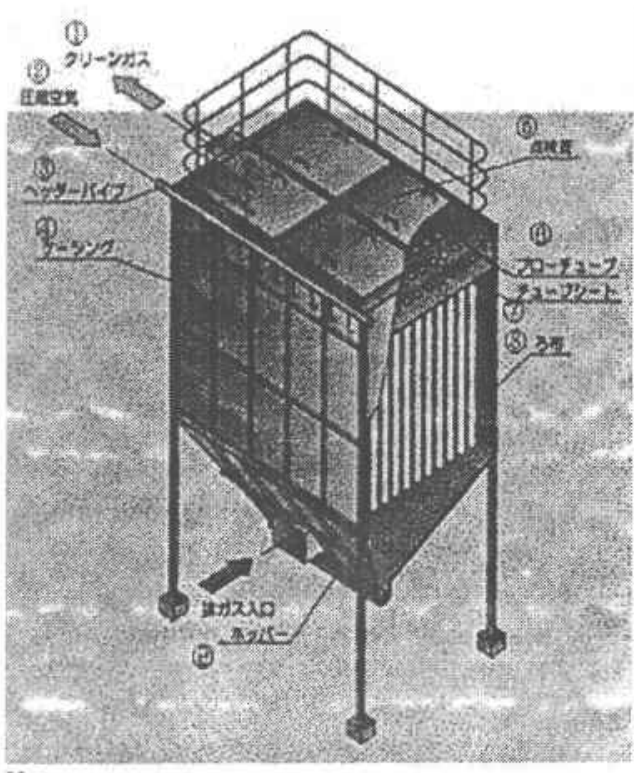

Keterangan

1. Gas Bersih keluar

6. Tabung peniup

2. Udara tekan

3. Pipa

4. Casing

5. Tutup pengecekan

7. Tabung Plate

8. Kain Filter

9. Hopper

Gambar 4. Penyaring gas hasil pembakaran

Beberapa perusahaan atau badan yang telah mulai mengembangkan metode ini diantaranya dikenal Proses Wellmann-Lord, proses batubara aktif, proses Walther dan Proses berkas elektron (electron beam /EB).

Proses pembersihan gas buang menggunakan mesin berkas elektron, melibatkan proses reaksi antara gas $\mathrm{NO}_{\mathrm{X}}$ dan $\mathrm{SO}_{\mathrm{x}}$ dengan bantuan berkas elektron yang dapat dijelaskan mekanismenya sbb: Gas $\mathrm{SO}_{\mathrm{X}}$ dioksidasi oleh radikal $\mathrm{OH}$ menjadi $\mathrm{HSO}_{3}$ yang cepat bereaksi menjadi hasil antara $\mathrm{HSO}_{5}$. Senyawa antara tsb. dengan adanya uap air dalam udara dapat bereaksi menjadi asam sulfat $\mathrm{H}_{2} \mathrm{SO}_{4}$ dan $\mathrm{O}_{2} \mathrm{H}$. Radikal ini mengoksidasi $\mathrm{NO}$ dan menghasilkan radikal untuk bereaksi selanjutnya. Sehingga Oksidasi $\mathrm{SO}_{2}$ meningkatkan oksidasi $\mathrm{NO}_{\mathrm{x}}$ menjadi $\mathrm{NO}_{2}{ }^{(1)}$. Dengan demikian konsumsi energi bisa rendah. Gas $\mathrm{SO}_{2}, \mathrm{NO}_{2}$, air dalam gas buang bereaksi menjadi gas asam sulfat dan asam nitrat. Asam-asam tersebut direaksikan dengan ammoniak menghasilkan ammonium sulfat dan ammonium nitrat yang bermanfaat untuk pupuk tanaman. Keuntungan terbesar dari proses ini adalah menghilangkan gas $\mathrm{NO}_{\mathrm{X}}$ dan $\mathrm{SO}_{\mathrm{X}}$ menghasilkan bahan yang berguna untuk tanaman.

\section{Penanganan Gas Buang dengan Berkas Elektron}

Penanganan gas buang dengan berkas elektron sangat efektif untuk menghilangkan sulfur dioksida $\left(\mathrm{SO}_{2}\right)$ dan Oksida-oksida nitrogen $\left(\mathrm{NO}_{\mathrm{X}}\right)$ dari gas sisa hasil pembakaran secara simultan. Proses ini merupakan proses kering menggunakan iradiasi berkas elektron dengan penambahan ammonia untuk mengkonversi oksidaoksida sulfur dan nitrogen garam ammonia. Garam ammoniak yang terbentuk serbuk mudah dipisahkan dengan menggunakan pengendapan elektron atau dengan filter kain. Garam ammoniak berupa ammonium sulfat dan ammonium nitrat dapat digunakan sebagai pupuk tanaman.

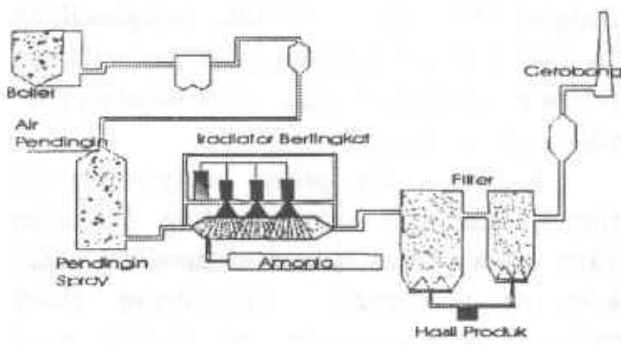

Gambar 5. Flow Diagram Penanganan Gas Buang dengan Berkas Elektron

Gas buang dimasukkan dalam bejana yang kemudian diiradiasi dengan berkas elektron sehingga gas buang tersebut terionisasi. Ion-ion yang terbentuk akan berinteraksi dengan komponen dalam gas buang menjadi atom bebas dan radikal seperti $\mathrm{O}, \mathrm{OH}, \mathrm{N}$ dan $\mathrm{HO}_{2}$. Atom bebas dan radikal tersebut berpotensi untuk bereaksi cepat dengan $\mathrm{SO}_{2}, \mathrm{NO}_{\mathrm{X}}$ dan air menjadi 
butiran halus dan uap asan $\operatorname{sulfat}\left(\mathrm{H}_{2} \mathrm{SO}_{4}\right)$ dan asam nitrat $\left(\mathrm{HNO}_{3}\right)$. Dengan adanya ammonia $\left(\mathrm{NH}_{3}\right)$ di sana, asam-asam akan bereaksi menjadi ammonium sulfat $\left(\left(\mathrm{NH}_{4}\right)_{2} \mathrm{SO}_{4}\right)$ dan ammonium nitrat $\left(\mathrm{NH}_{4} \mathrm{NO}_{3}\right)$.

Reaksi yang terjadi dalam proses penanganan gas buang dengan berkas elektron sbb:

Pembentukan Radikal bebas

$\mathrm{N}_{2}, \mathrm{O}_{2}, \mathrm{H}_{2} \mathrm{O}+\mathrm{e} \rightarrow \mathrm{OH}^{*} \mathrm{O}^{\circ}, \mathrm{HO}_{2}{ }^{\circ}, \mathrm{N}^{*}$

Oksidasi $\mathrm{SO}_{2}$ dan pembentukan $\mathrm{H}_{2} \mathrm{SO}_{4}$

$$
\begin{aligned}
& \mathrm{SO}_{2}+\mathrm{O}^{*} \rightarrow \mathrm{SO}_{3} \\
& \mathrm{SO}_{3}+\mathrm{H}_{2} \mathrm{O} \rightarrow \mathrm{H}_{2} \mathrm{SO}_{4} \text { atau } \\
& \mathrm{SO}_{2}+\mathrm{OH}^{*} \rightarrow \mathrm{HSO}_{3} \\
& \mathrm{HSO}_{3}+\mathrm{O}^{*} \rightarrow \mathrm{H}_{2} \mathrm{SO}_{4}
\end{aligned}
$$

Oksidasi $\mathrm{NO}_{2}$ dan pembentukan $\mathrm{HNO}_{3}$

$$
\begin{aligned}
& \mathrm{NO}+\mathrm{O}^{*} \rightarrow \mathrm{NO}_{2} \\
& \mathrm{NO}_{3}+\mathrm{OH}^{*} \rightarrow \mathrm{HNO}_{3} \text { atau } \\
& \mathrm{NO}+\mathrm{O}_{2} \mathrm{H}^{*} \rightarrow \mathrm{NO}_{2} \\
& \mathrm{NO}_{2}+\mathrm{OH}^{*} \rightarrow \mathrm{HNO}_{3}
\end{aligned}
$$

$$
\begin{aligned}
& \mathrm{NO} \underset{\mathrm{N}^{*}, \mathrm{NH}_{2}}{\mathrm{NH}_{2}} \mathrm{~N}_{2} \text { (NO 20\%) } \\
& \left.\mathrm{NO}_{2} \rightarrow \mathrm{N}_{2} \mathrm{O} \text { (NO } 10 \%\right)
\end{aligned}
$$

Reaksi asam dengan $\mathrm{NH}_{3}$

$$
\begin{aligned}
& \mathrm{H}_{2} \mathrm{SO}_{4}+2 \mathrm{NH}_{3} \rightarrow\left(\mathrm{NH}_{4}\right)_{2} \mathrm{SO}_{4} \\
& \mathrm{HNO}_{3}+\mathrm{NH}_{3} \rightarrow \mathrm{NH}_{4} \mathrm{NO}_{3}
\end{aligned}
$$

Penghilangan $\mathrm{SO}_{2}$ oleh panas

$$
\begin{aligned}
& \left(\mathrm{NH}_{3}\right) \mathrm{SO}_{2}+2 \mathrm{H}_{2} \mathrm{O} \rightarrow\left(\mathrm{NH}_{3}\right)_{2} \mathrm{SO}_{4} \\
& \left(\mathrm{NH}_{3}\right) \mathrm{SO}_{2}+2 \mathrm{H}_{2} \mathrm{O} \rightarrow\left(\mathrm{NH}_{4}\right)_{2} \mathrm{SO}_{4}
\end{aligned}
$$

\begin{tabular}{|c|c|c|c|c|c|c|}
\hline \multirow{2}{*}{ No } & \multirow{2}{*}{ Tahun } & \multicolumn{2}{|l|}{ Institusi } & \multirow{2}{*}{$\begin{array}{c}\text { Kecepatan Alir } \\
\mathrm{Nm}^{3} / \mathrm{jam}\end{array}$} & \multirow{2}{*}{$\begin{array}{l}\text { Akselerator } \\
\mathrm{KW} / \mathrm{MeV}\end{array}$} & \multirow{2}{*}{ Type Gas Buang } \\
\hline & & Nama & Negara & & & \\
\hline 1 & $1970-1971$ & Ebara & Japan & 0.02 & $1.2 / 2-12$ & Simulated \\
\hline 2 & $1972-1974$ & Jaeri & Japan & 60 & $15 / 1.5$ & Simulated \\
\hline 3 & $1974-1977$ & Ebara & Japan & 1.000 & $30 / 0.750$ & Heavy oil \\
\hline 4 & $1977-1978$ & Ebara & Japan & 10.000 & $90 / 0.750$ & Sinter plante \\
\hline 5 & 1981 & University of Tokio & Japan & 84 & $0.12 / 1.0$ & simulated \\
\hline 6 & $1984-1985$ & Research Cortrell & USA & 5.300 & $80 / 0.800$ & Coal \\
\hline 7 & $1984-1988$ & Ebara & USA & 24.000 & $160 / 0.800$ & Coal \\
\hline 8 & $1981-1991$ & Jaeri & Japan & 0.9 & 11.5 & Heavy oil \\
\hline 9 & $1984-1988$ & KIK & FRG & $300-1.000$ & $3.6 / 0.300$ & Nat.gas \\
\hline 10 & $1984-1991$ & University Karlsruhe & FRG & 1.000 & $22 / 0.220$ & Coal \\
\hline 11 & $1985-1989$ & Bedenwerk & FRG & 20.000 & $180 / 0.300$ & \\
\hline 12 & 1989 & KIK & FRG & 1.500 & $16.5 / 0.550$ & Light oil \\
\hline 13 & 1991 & INCT & Poland & 20.000 & $100 / 0.700$ & Coal \\
\hline 14 & 1992 & NKKIJaeri & Japan & 1.000 & $50 /<1.000$ & Incinerator \\
\hline 15 & 1992 & Ebara & Japan & 50.000 & $80 / 0.800$ & Tunnel \\
\hline 16 & 1993 & Ebara/Jaeri & Japan & 12.000 & $108 / 0.800$ & Coal \\
\hline
\end{tabular}

Penelitian penggunaan berkas elektron telah dimulai 30 tahun terakhir menggunakan gas simulasi dan akselerator untuk penelitian dengan daya kecil. Dimulai oleh Ebara Jepang, saat ini sudah sampai pada penggunaan akselerator skala industri dengan kecepatan alir gas $620.000 \mathrm{Nm}^{3} / \mathrm{jam}$ setara dengan tenaga 220 MW menggunakan akselerator $800 \mathrm{KeV} 400 \mathrm{KW}$ per unit. Data akselerator penelitian yang pernah dibuat dapat dilihat dalam Tabel 3 dan untuk skala industri dilihat dalam Tabel 4 .

Tabel 3. Akselerator untuk eksperiment untuk penanganan gas buang 
Tabel 4. Akselerator penanganan gas buang untuk industri

\begin{tabular}{|c|c|c|c|c|c|c|c|c|c|}
\hline \multirow{2}{*}{ No } & \multirow{2}{*}{ Th } & \multicolumn{2}{|c|}{ Institusi } & \multirow{2}{*}{ Keterangan } & \multirow{2}{*}{\begin{tabular}{|l|} 
Kec. Alir \\
Nmj/jam \\
\end{tabular}} & \multirow{2}{*}{\begin{tabular}{|c|} 
Produk \\
$\mathrm{Kg} / \mathrm{j}$
\end{tabular}} & \multirow{2}{*}{$\begin{array}{l}\text { Akselerator } \\
\text { MW/MeV }\end{array}$} & \multirow{2}{*}{\begin{tabular}{|c|}
$\begin{array}{c}\text { Polutan, } \\
\text { ppm }\end{array}$ \\
\end{tabular}} & \multirow{2}{*}{ Efisiensi } \\
\hline & & Nama & Negara & & & & & & \\
\hline 1 & 1998 & $\begin{array}{l}\text { Chengdu } \\
\text { Thermal } \\
\text { Power Plant }\end{array}$ & China & $\begin{array}{l}1 \text { seri dengan dua } \\
\text { akselerator }\end{array}$ & 300.000 & 2.470 & $\begin{array}{l}640 \mathrm{kWl} \\
800 \mathrm{KeV} \\
400 \mathrm{~mA} / \text { unit }\end{array}$ & $\begin{array}{l}\mathrm{SO}_{2}: 1.800 \\
\mathrm{NO} x: 400 \\
\text { Dust }\end{array}$ & $\begin{array}{l}80 \% \\
10 \% \\
<200 \mathrm{mg} / \mathrm{m}^{3} \\
\end{array}$ \\
\hline 2 & 1999 & $\begin{array}{l}\text { Pomorzani } \\
\text { Electric Power }\end{array}$ & Polandia & $\begin{array}{l}2 \text { seri masing- } \\
\text { masing } 2 \\
\text { akselerator }\end{array}$ & 275.000 & & $\begin{array}{l}1200 \mathrm{kWI} \\
800 \mathrm{KeV} \\
300 \mathrm{~kW} / \mathrm{unit}\end{array}$ & $\begin{array}{l}\mathrm{SO}_{2}: 5.500 \\
\mathrm{NO}_{x}: 390\end{array}$ & $\begin{array}{l}85 \% \\
70 \%\end{array}$ \\
\hline 3 & 1999 & $\begin{array}{l}\text { Nishi-Nagara } \\
\text { Thermal Power } \\
\text { Plant }\end{array}$ & Jepang & $\begin{array}{l}3 \text { seri masing- } \\
\text { masing } 2 \\
\text { akselerator }\end{array}$ & 620.000 & 4.500 & $\begin{array}{l}2400 \mathrm{kWl} \\
800 \mathrm{KeV}\end{array}$ & & \\
\hline 4 & & $\begin{array}{l}\text { CET - South } \\
\text { Bucharest } \\
\text { Project }\end{array}$ & Rumania & $\begin{array}{l}5 \text { seri masing- } \\
\text { masing } 2 \\
\text { akselerator }\end{array}$ & & & $\begin{array}{l}4000 \mathrm{kWl} \\
800 \mathrm{KeV}\end{array}$ & & \\
\hline
\end{tabular}

Tabel 5. Perbandingan Bebarapa Proses Pengurangan gas $\mathrm{NO}_{\mathrm{x}}$ dan $\mathrm{SO}_{2}$

\begin{tabular}{|c|c|c|c|}
\hline & Pembakaran Ulang & Penyerapan & Berkas elektron \\
\hline Proses & $\begin{array}{l}\text { Meminimumkan } \mathrm{NOx} \\
\text { dengan pembakaran } \\
\text { ulang } \mathrm{NOx} \text { menjadi } \mathrm{N}_{2}\end{array}$ & $\begin{array}{l}\text { Penyerapan gas } \mathrm{SO}_{2} \\
\text { dengan basa Calsium } \\
\text { menjadi gibsun }\end{array}$ & $\begin{array}{l}\text { Aktivasi } \mathrm{NO} \times \text { san } \mathrm{SO}_{2} \\
\text { menjadi asam nitrat dan } \\
\text { asam sulfat, direaksikan } \\
\text { dengan ammoniak }\end{array}$ \\
\hline $\begin{array}{l}\text { Keuntungan/ } \\
\text { kerugian }\end{array}$ & $\begin{array}{l}\text { 1. Sederhana } \\
\text { 2. Menghilangkan NOx } \\
\text { 3. Kerugian Penyerapan } \\
\text { basah } \\
\text { 4. Lebih banyak limbah } \\
\text { cair yang dihasillkan. } \\
\text { 5. Biaya operasional } \\
\text { tinggi }\end{array}$ & $\begin{array}{l}\text { 1. Sederhana } \\
\text { 2. Menghilangkan } \mathrm{SO}_{2} \\
\text { 3. Penyerapan basah } \\
\text { 4. Lebih banyak limbah } \\
\text { cair yang dihasillkan. } \\
\text { 5. Biaya operasional } \\
\text { tinggi }\end{array}$ & $\begin{array}{l}\text { 1. Kompleks } \\
\text { 2. Bisa simultan } \\
\text { menghilangkan } \mathrm{SO}_{2} \\
\text { dan } \mathrm{NOx} \\
\text { 3. Penyerapan : kering } \\
\text { 4. Tidak dihasilkan limbah } \\
\text { cair } \\
\text { 5. Biaya Operasional } \\
\text { rendah }\end{array}$ \\
\hline Hasil samping & Hasil samping tidak ada & $\begin{array}{l}\text { Hasil samping adalah } \\
\text { gibsun, yang nilai ekonomis } \\
\text { kecil }\end{array}$ & $\begin{array}{l}\text { Ammonium sulfat dan } \\
\text { ammonium nitrat nilai } \\
\text { ekonomis tinggi ( } 200.000 \\
\text { ton/th }=14 \text { milyar } \$ / \text { th untuk } \\
550 \text { Mwe plat) }\end{array}$ \\
\hline Biaya investasi & & $\begin{array}{l}\text { Modal Pokok (\$/kW) 100- } \\
150 \text { (Lama) dan }(\$ / k W) 70 \text { - } \\
150 \text { (baru }\end{array}$ & $\begin{array}{l}\text { Biaya investasi } 150-200 \\
\$ / K w e\end{array}$ \\
\hline $\begin{array}{l}\text { Biaya } \\
\text { Operasional }\end{array}$ & & $\begin{array}{l}\text { Variabel O\&M Usmills/kWj } \\
\text { 1,5-3,3 (lama) 1,3-3,2 } \\
\text { (baru), Total O\&M } \\
\text { Usmills/kWj 6,6-12 (lama) } \\
\text { 7,4-13,0 (baru) }\end{array}$ & $\begin{array}{l}\text { Biaya berkas elektron } 2 \$ / W \\
\text { dan kira-kira } 10 \% \text { ciari total } \\
\text { invesment. }\end{array}$ \\
\hline $\begin{array}{l}\text { Kemampuan } \\
\text { membersihkan } \\
\text { gas }\end{array}$ & Menghilangkan $60 \% \mathrm{NOx}$ & $\begin{array}{l}\text { Menghilangkan } 80-95 \% \\
\mathrm{SO}_{2} \text { (95-99\% dengan aditif } \\
\text { Mg atau asam adipik) }\end{array}$ & $\begin{array}{l}\text { Menghilangkan } 90 \% \mathrm{SO}_{2} \\
\text { dan } 40-65 \% \mathrm{NOx}\end{array}$ \\
\hline Plant yang ada & & $\begin{array}{l}\text { Kapasitas } 1000 \mathrm{MW} \text { dengan } \\
\text { boiler } 360 \mathrm{KW}\end{array}$ & $4000 \mathrm{~kW} / 800 \mathrm{KeV}$ \\
\hline
\end{tabular}




\section{PEMBAHASAN}

Pengurangan kadar gas berbahaya dalam gas buang hasil pembakaran telah dilakukan dengan berbagai cara. Cara pertama yang dilakukan adalah dengan cara preventif yaitu mencegah terbentuknya gas berbahaya dengan pembakaran kembali gas hasil pembakaran. Cara kedua adalah dengan pengelolaan gas hasil pembakaran seperti cara penyerapan, atau dengan pembentukan radikal bebas menggunakan berkas elektron agar terjadi reaksi menjadi gas stabil asam nitrat dan asam sulfat yang bisa direaksikan dengan ammoniak menjadi ammonium sulfat dan ammonium nitrat.

Bila dibandingkan beberapa cara di atas, masing-masing mempunyai keuntungan dan kerugian masing-masing. Berkas elektron sekaligus menghilangkan $\mathrm{SO}_{2}$ dan $\mathrm{NO}_{\mathrm{X}}$ sedang proses penyerapan, kemampuan penyerap basa kalsium adalah menyerap gas $\mathrm{SO}_{2}$. Penyerapan gas $\mathrm{NO}_{\mathrm{X}}$ tidak sempurna sehingga banyak yang masih terbawa oleh gas. Gas $\mathrm{NO}_{\mathrm{X}}$ merusak lingkungan dan berbahaya bagi kesehatan. Sehingga untuk mengurangi dampak $\mathrm{NO}_{\mathrm{X}}$ tersebut, penyerapan $\mathrm{SO}_{2}$ perlu dilengkapi dengan pengurangan terbentuknya $\mathrm{NO}_{\mathrm{X}}$. Cara yang sudah terbukti mengurangi kandungan $\mathrm{NO}_{\mathrm{X}}$ dalam hasil pembakaran adalah dengan proses pembakaran kembali $\mathrm{NO}_{\mathrm{x}}$. Prinsipnya hasil pembakaran yang mengandung $\mathrm{NO}_{\mathrm{x}}$ dilewatkan proses pembakaran dengan kekurangan oksigen, yang mendorong terbentuknya senyawa radikal yang memacu reaksi pembentukan $\mathrm{N}_{2}$. Pada tahap ketiga reaksi pada suhu rendah untuk menyempurnakan reaksi.

Penyerapan gas $\mathrm{NO}_{\mathrm{x}}$ yang tidak memalui proses pembakaran ulang, bisa dilakukan dengan cara reduksi katalitis selektif atau reduksi non katalitis selektif. Tetapi cara ini lebih rumit, sehingga perlu biaya yang tinggi.

Penyerapan gas $\mathrm{SO}_{2}$ merupakan proses penghilangan setelah pembakaran. Gas dikontakkan dengan cairan penyerap yang mengandung bahan penyerap kalsium hidroksida. Reaksi akan terjadi antara gas $\mathrm{SO}_{2}$ dengan kalsium hidroksida dan oksigen dari udara tekan yang dimasukkan dalam tangki sulfit. Endapan yang terbentuk adalah kalsium sulfat atau gibsun yang digunakan untuk keperluan bangunan. Untuk menghilang-kan gas $\mathrm{NO}_{\mathrm{X}}$ dan $\mathrm{SO}_{2}$, diperlukan kombinasi proses antara penyerapan $\mathrm{NO}_{\mathrm{X}}$ menggunakan pembakaran kembali $\mathrm{NO}_{\mathrm{X}}$ atau proses reduksi baik menggunakan katalisator maupun tidak, dan proses penyerapan gas $\mathrm{SO}_{2}$ menghasilkan gibsun. Proses tersebut meskipun sederhana dan biaya investasi rendah, tetapi memerlukan biaya operasional yang lebih besar dan menghasilkan limbah cair yang cukup banyak. Perbandingan proses-proses tersebut sudah penulis rangkup dalam Tabel 5 .

Proses penghilangan gas berbahaya menggunakan berkas elektron mempunyai banyak keuntungan. Proses penyerapan sepenuhnya menggunakan proses kering sehingga tidak menimbulkan limbah baru. Hasil sampingnya juga berupa ammonium nitrat dan ammonium sulfat yang dipergunakan sebagai pupuk. Proses juga dapat menghilangkan gas $\mathrm{NO}_{\mathrm{X}}$ dan $\mathrm{SO}_{2}$ secara simultan.

\section{KESIMPULAN}

1. Gas Hasil Pembakaran mengandung gas-gas berbahaya utamanya $\mathrm{NO}_{\mathrm{X}}(\mathrm{NO}$, $\left.\mathrm{NO}_{2}, \mathrm{~N}_{2} \mathrm{O}\right), \mathrm{SO}_{2}, \quad \mathrm{SO}_{3}$ yang bisa menyebabkan hujan asam, merusakkan ozon di Stratosfir, merusakkan hutan atau tanah pertanian, menyebabkan korosi dan menyebabkan problem kesehatan bagi manusia dan hewan.

2. Gas $N_{\mathrm{X}}$ dapat dikurangi dengan mencegah terjadi gas $\mathrm{NO}_{\mathrm{X}}$ melalui pembakaran ulang dari gas hasil pembakaran dengan pengurangan udara yang menyebabkan terbentuknya radikal sehingga gas $\mathrm{NO}_{\mathrm{X}}$ bereaksi menjadi $\mathrm{N}_{2}$, dilanjutkan dengan penyempurnaan reaksi dengan pemberian udara pada suhu rendah. 
3. Penyerapan $\mathrm{NO}_{\mathrm{x}}$ dalam hasil pembakaran dapat juga dilakukan dengan reaksi reduksi baik secara katalitis maupun non katalitis.

4. Penyerapan gas $\mathrm{SO}_{2}$ dilakukan dalam kolom absorbsi dengan mengkontakkan gas hasil pembakaran dengan penyerap kalsium hidroksida, menghasilkan gibsun

5. Cara baru untuk penyerapan gas $\mathrm{NO}_{\mathrm{X}}$ dan $\mathrm{SO}_{2}$ secara simultan dilakukan dengan iradiasi gas dengan berkas elektron.

6. Penghilangan gas dengan berkas elektron memerlukan investasi yang lebih besar, tetapi biaya operasional lebih kecil sehingga biaya keseluruhan menjadi lebih kecil.

\section{DAFTAR PUSTAKA}

1. TURHAN S., KARADENIZ S., TUGLUOGLU N., EKEN N., OKTAR O., DAN ERCAR I., Technical and Economical Aspects of $\mathrm{SO}_{2}$ and $\mathrm{NO}_{\mathrm{X}}$ Removal from Lue Gas By Electron Beam Irradiation, Ankara Nuclear Research and Training Center (ANRTC), Ankara, http://www.atom. gov.tr/taek/dudnaen/yayintar/yayintar p df/fundamental/fundamental-52.pdf.

2. Technology for $\mathrm{SO}_{2}$ and $\mathrm{NO}_{\mathrm{X}}$, Reduction From Combustion Flue Gas By energitic Electron Induced Plasma Process And Electric Discharge http://www.vonrolli nc.com/downloads/fluegas.pdf.
3. Maklumat, Minyak Bumi Indonesia cukup 22 tahun, Maklumat, 11 Februari 2004.

4. Kompas, Cadangan Minyak Bumi Hanya Cukup untuk 7 Tahun Lagi, Kompas 13 Desember 2003.

5. Deputi PTEN, Persiapan Batan Menghadapi Pembangunan PLTN, Presentasi Trainee, Hasil Penelitian dan Kegiatan P2PLR th 2003, Jakarta, 2004.

6. RADIAN CORPORATION, Summary Report : Control of $\mathrm{NO}_{\mathrm{X}}$ Emission by Reburning, Emvironmental Protection Agency, Washington DC, 1996, http://www.epa.gov/ORD/NRMRL/pubs 1625r96001/625r96001.pdf.

7. THE WORLD BANK GROUP, Wet Flue Gas Desulfurification, http://ww w.worldbank.org/html/fpd/em/power/EA /mitigatn/aqsowet.htm.

8. CHANG J.S., Integrated ElectrostaticNon-Thermal Plasma Flue Gas Clening Systems, Department of Engineering Physics, Hamilton.

9. MARITSA-East2.tpp.plg Flue Gas Desulphurization, MM2, http://www.b ulgaria.donino.bg/tec2/eng/tec2.6.htm.

10. BEARDSWOTTH E., UFTO Note- EBeam Stack Gas Scubbing.

11. ZIMEK Z., RZEWUSKI H., MIGDAT W., Electron Accelerators Installed at The Institute of Nuclear Chemistry and tecnonogy, Kronika Kola Naukowego Fizykow CAMAC. 